Derecho penal 



\title{
Convenciones o estipulaciones probatorias $y$ su aplicación en el Perú: un estudio dogmático-empírico
}

\author{
Javier Aguirre Chumbimuni
}

\section{Introducción}

Desde siempre, en un proceso penal existen intereses contrapuestos $-\mathrm{y}$ muchas veces irreconciliables - en juego, lo que convierte al conflicto -y al proceso que como consecuencia de este se origina - en un trámite excesivamente largo y hasta engorroso, al cabo del cual - en la gran mayoría de casos - la solución emitida por el órgano jurisdiccional no cubre las expectativas ni de una ni de otra parte.

Esta concepción del proceso penal es la que ha primado hasta el inicio del proceso de reforma procesal penal en América Latina; sin embargo, con la promulgación y puesta en aplicación de los códigos procesales penales, inspirados en el sistema acusatorio, nuestro concepto de administración de justicia penal parece haber cambiado. El nuevo ordenamiento procesal penal ha previsto fórmulas de justicia negociada, ${ }^{1}$ figuras procesales mediante las cuales, las partes en conflicto - fiscal e imputado - tienen la posibilidad de negociar y arribar a acuerdos satisfactorios para los intereses de uno y otro.

1 Este término tiene su origen en el plea bargaining (pedido de negociación) del derecho procesal norteamericano, que "consiste en la obtención por el acusado de una serie de concesiones oficiales a cambio de declararse culpable". Citado por Rodríguez Baca (1997: 34). 
Estos acuerdos suponen negociaciones con diversos efectos en el proceso penal; así, es posible la negociación tanto para facilitar un juicio que no pudo evitarse - filtrando los hechos objeto de prueba y los medios de prueba que serán actuados en el debate oral - como para impedir un juicio, arribando a acuerdos, satisfaciendo la necesidad de reparación del agraviado y la facultad de sanción del Estado, mediando el previo reconocimiento de responsabilidad por parte del imputado.

De esa manera, en virtud de la justicia negociada recogida en los nuevos ordenamientos procesales penales en América Latina, se hace posible que el conflicto sometido a conocimiento de los órganos jurisdiccionales concluya mediante convenios propuestos por las partes, acuerdos que, para ser admitidos e incorporados por el juez, requieren que este controle la legalidad de su contenido.

A la luz de los resultados obtenidos hasta la fecha en el Perú, reflejados en los informes emitidos con motivo de la aplicación progresiva del Código Procesal Penal $2004^{2}$ (en adelante, CPP04), se observa que las instituciones de justicia negociada - a pesar de ser novedosas - están siendo aplicadas de manera significativa, incidiendo positivamente en la disminución de la carga procesal de los órganos jurisdiccionales: un gran número de procesos han concluido sin necesidad de juicio oral, en virtud de acuerdos adoptados por las partes, pero no ha habido ninguna referencia a las estipulaciones o convenciones probatorias, lo que lleva a pensar en la poca o nula incidencia de su aplicación en algunos distritos judiciales.

Este hallazgo inspira esta investigación, en la que además de examinar dogmáticamente la figura procesal de estipulaciones o convenciones probatorias, intentamos acercarnos a su aplicación en la práctica procesal actual, para, a partir de allí, poder descubrir y analizar las principales razones que explican que no se haya aplicado con la misma incidencia que las demás instituciones de justicia negociada legisladas por el CPP04.

Las razones presentadas en esta investigación se encuentran respaldadas por las respuestas obtenidas a una encuesta realizada a jueces, fiscales y abogados que aplican día a día las disposiciones del CPP04. A partir de ellas, hemos construido propuestas de mejora, a fin de incre-

2 Para mayores referencias, revisar en $<$ http://historico.pj.gob.pe/CorteSuprema/ ncpp/index.asp?opcion=informes $>$ o en $<$ http://www.minjus.gob.pe/cpp/docu $>$. 
mentar el uso de las convenciones probatorias como instrumento facilitador del debate contradictorio en el juicio oral.

\section{Sistema acusatorio}

Desde hace algunos años, en muchos países de América Latina se ha iniciado una reforma del proceso penal con la finalidad de que el sistema de justicia en este ámbito sea más eficiente y garantista. Esta reforma implica no solo una modificación de la legislación procesal existente, sino además involucra un cambio radical del sistema. La esencia del cambio no es la sustitución de una legislación por otra, sino el establecimiento, instalación e incorporación, como parte de la cultura de los aplicadores de justicia, del sistema acusatorio; se trata de lograr que este y sus principios inspiren cada una de sus actuaciones, dejando de lado el sistema inquisitivo y la escrituralidad como una de sus principales manifestaciones. Ese es el principal reto.

Este otro sistema inspirador de nuestros códigos procesales, recientemente promulgados, no solo introduce una nueva estructura del proceso penal, sino que otorga a cada uno de los actores procesales - fiscales, jueces y abogados - un nuevo rol dentro del proceso, implicando un desafío para cada uno de ellos y requiriendo la obtención y desarrollo de nuevos conocimientos y habilidades para superarlo.

Entre las habilidades que este otro sistema demanda se encuentra la negociación, que incorpora una serie de instituciones de justicia negociada en virtud de las cuales las partes en litigio - fiscal e imputado- pueden decidir desde ponerle fin al conflicto sin necesidad de juicio oral, hasta arribar a acuerdos para lograr un juicio más rápido y expeditivo.

Dentro de este último contexto es que tiene lugar la figura procesal de las estipulaciones o convenciones probatorias; así, mientras los acuerdos reparatorios y el principio de oportunidad ponen fin al conflicto sin necesidad de pronunciamiento judicial en un proceso penal, y la terminación anticipada permite al juez, previo acuerdo entre las partes, concluir un proceso penal con una sentencia sin necesidad de juicio oral, la estipulación o convención probatoria tiene lugar en los casos en los que el juicio no pudo ser evitado, y en virtud de ella las partes toman acuerdos cuyo objetivo es facilitar el debate contradictorio en el juicio oral, haciéndolo más dinámico y sencillo. 


\section{Aspecto dogmático de las estipulaciones o convenciones probatorias}

\subsection{Etimología y concepto}

\subsubsection{Etimología}

Según el Diccionario de la lengua española, estipulación significa "convenio verbal" (RAE 2001: V, 676). Por su parte, convenio significa "ajuste, convención, contrato", y proviene del verbo convenir, que implica "ser de un mismo parecer o dictamen" (RAE 2001: III, 437).

Por otra parte, convención significa "ajuste y concierto entre dos o más personas o entidades".

Ambos términos se refieren a un acuerdo sobre una materia determinada, con la diferencia de que la estipulación es de naturaleza verbal, mientras que la convención no precisa modo alguno.

La palabra probatorio significa "que sirve para probar o averiguar la verdad de algo" (RAE 2001: VIII, 1246).

Etimológicamente, convención o estipulación probatoria ${ }^{3}$ es un acuerdo entre dos personas (en este caso, dos sujetos procesales) sobre hechos o instrumentos que se utilizan para probar una afirmación (medio de prueba).

\subsubsection{Concepto}

Para el procesalista colombiano Silva Corredor, las estipulaciones probatorias:

[...] no son más que acuerdos entre fiscalía y defensa en los que se establece como demostrados unos hechos o circunstancias, sin que ello implique terminación anticipada del proceso o renuncia, interrupción o suspensión de la acción penal o inmunidad para el sujeto agente. Las estipulaciones se realizan y tienen su razón de ser siempre que se llegue a audiencia de juicio oral [...] (AA.VV. 2005: 148).

3 A lo largo de este trabajo utilizaremos indistintamente cualquiera de los dos términos, aunque nos parece más apropiado convención, pues desde el punto de vista etimológico resulta más amplio que estipulación, ya que este último solo hace referencia a un acuerdo verbal. 
En derecho de familia, se define a las convenciones probatorias como:

Acuerdo al que llegan las partes en conflicto para solicitar al juez que dé por acreditados ciertos hechos, de manera que no es necesario probarlos ante el tribunal. ${ }^{4}$

A manera de conclusión, puede entonces sostenerse que las estipulaciones o convenciones probatorias son una de las tantas expresiones de la justicia penal negociada, propia del sistema acusatorio, inspirador de la reforma procesal penal en América Latina. Constituyen acuerdos entre las partes de un proceso penal respecto a hechos, circunstancias o medios de prueba; si convienen sobre los dos primeros, serán tenidos como ciertos en el juicio oral y no deberán ser probados; si el acuerdo es sobre los medios de prueba, entonces solo la prueba acordada servirá para probar determinado hecho. ${ }^{5}$

\subsection{Finalidad e importancia}

Las estipulaciones o convenciones probatorias tienen por finalidad ayudar a la agilidad y dinamicidad del proceso, en especial al desarrollo del juicio oral, dotándolo de celeridad y haciéndolo más económico, evitando el debate y actuación de medios de prueba respecto a hechos no controvertidos o aceptados por ambas partes, para no prolongar el debate de manera innecesaria.

Cuando las partes arriban a estipulaciones o convenciones probatorias, el juicio oral se simplifica, privilegiándose el principio de celeridad y economía procesal, encaminándolo al logro de una respuesta pronta por parte del juzgador.

En efecto, si la esencia del juicio oral es el debate (lo que implica contraposición de argumentos), no resulta coherente con los principios de economía y celeridad procesales que se pretenda actuar medios de prueba respecto a hechos sobre los cuales la Fiscalía y la defensa están de acuerdo. Si hay consenso, no hay debate y, por tanto, no hay contradictorio, con lo que se evita que el juicio oral se dilate en forma innece-

4 Guía práctica de los juzgados de familia: palabras de uso frecuente. <http://www.minjusticia.cl/familia/documentos/guiarm.pdf $>$.

5 Esta última posibilidad - a diferencia de las demás legislaciones que aquí analizamos- está contemplada solo en el CPP04 peruano. 
saria y se propicia un entorno más ágil y dinámico de desarrollo de dicho juicio.

\section{Las estipulaciones o convenciones probatorias en el derecho comparado}

\subsection{Venezuela}

En Venezuela, la reforma de su sistema procesal penal se instauró en 1999 y, al igual que en los demás países de América Latina, ella ha implicado un cambio del sistema inquisitivo al sistema acusatorio.

Conservando el rasgo característico del sistema acusatorio, Venezuela ha incluido dentro de su regulación procesal una serie de figuras de justicia negociada, entre otras la que es objeto del presente trabajo; su Código Orgánico Procesal Penal, en su artículo 200, la ha denominado estipulación probatoria:

Si todas las partes estuvieren de acuerdo en alguno de los hechos que se pretenden demostrar con la realización de determinada prueba, podrán realizar estipulaciones respecto a esa prueba, con la finalidad de evitar su presentación en el debate del juicio oral.

De tales estipulaciones deberá quedar constancia expresa en el auto de apertura a juicio, y las partes podrán alegarlas en el debate, sin necesidad de incorporarlas por algún medio de prueba. No obstante, si el tribunal lo estima conveniente, ordenará su presentación.

Según la legislación procesal venezolana, es posible arribar a una estipulación probatoria cuando existe acuerdo entre las partes acerca de un hecho que se pretende demostrar a través de una prueba. ${ }^{6} \mathrm{Si}$ se presentare tal situación, las partes pueden acordar que la(s) prueba(s) que tenga(n) por finalidad acreditar el hecho sobre el cual hay acuerdo no sea(n) actuada(s) en el juicio oral, lo que implica que no será(n) admitida(s) ni sometida(s) al contradictorio.

6 Apreciamos aquí que el consenso entre Fiscalía y defensa es sobre un hecho, pero lo que se somete a estipulación probatoria (es decir, lo que no se actúa en juicio oral) es la prueba que pretende demostrar ese hecho. La prueba sobre ese hecho no controvertido no es sometida al contradictorio. 
En consecuencia, su finalidad es agilizar el debate y evitar actuar medios de prueba sobre hechos no controvertidos, los cuales serán valorados por el Juzgado de Juicio como ciertos. La finalidad de las convenciones probatorias quedó establecida en la ejecutoria del Tribunal Supremo de Justicia de Venezuela, en la que se señaló:

Entonces como consecuencia del pacto que sobre estipulaciones probatorias accedieren las partes, su efecto inmediato no sería otro que tener por demostrados los hechos sin necesidad de incorporar al debate oral las pruebas que los acreditan, alterándose de ese modo el principio que rige la carga de la prueba en el sistema acusatorio, constituyendo una excepción al principio de necesidad de la prueba. ${ }^{7}$

Además, el Código Procesal establece que las estipulaciones probatorias deberán constar de manera expresa en el auto de apertura a juicio; para ello, tendrá que observarse el plazo y forma de presentación, y las estipulaciones serán propuestas por escrito hasta cinco días antes de la fecha fijada para la audiencia preliminar. ${ }^{8}$

Respecto al momento en que deben ser planteadas las estipulaciones probatorias, el Juzgado de Primera Instancia en lo Penal del Circuito Judicial Penal del Estado de Aragua se ha pronunciado así:

En cuanto a la oportunidad para pactar estipulaciones [...] si bien es cierto se establece en el código que es cinco días antes de la audiencia preliminar, es criterio de este tribunal que si las partes proponen tales estipulaciones durante el juicio ambas se encuentran obviamente de acuerdo en que la evacuación de las mismas se hace innecesaria, ya que lo que probarían estos medios de prueba no es discutido por las partes y no forma parte por tanto del "thema decidendum".

$\mathrm{Al}$ encontrarse de acuerdo las partes no se violenta el principio de preclusividad en materia probatoria, ya que este, tal como asevera

7 Para mayores detalles, ver Ejecutoria del Tribunal Supremo de Justicia de Venezuela, exp. RP11-P-2005-005054, del 7 de noviembre del 2006 (tercer considerando). <http://sucre.tsj.gov.ve/decisiones/2006/noviembre/1220-7-RP11-P-2005005054-.html>.

8 El Código Orgánico Procesal Penal de Venezuela prevé, en forma similar al peruano, que la acusación sea notificada a las partes antes de la realización de la audiencia preliminar. 
Roberto Delgado Salazar, 9 "rige como garantía para las partes en el sentido de que cada una se atenga a las oportunidades dadas para actuar a fin de que las otras puedan conocer y controlar oportunamente las pruebas que se ofrecen e incorporar, en el caso planteado, las que se omiten, con lo que se persigue impedir que se sorprenda al adversario con prueba o actuaciones de último momento y que no alcance a controvertir o que se propongan cuestiones sobre las cuales no pueda ejercitar su defensa, que no sería el caso [...]. ${ }^{10}$

De dicho pronunciamiento se concluye que, aunque las estipulaciones probatorias fueron planteadas por las partes en una etapa posterior a la establecida por el Código Orgánico, el juez puede admitirlas atendiendo a su finalidad de no dilatar el debate con la actuación de medios de prueba respecto a hechos no controvertidos.

Por otro lado, los acuerdos contenidos en las estipulaciones probatorias, según la legislación venezolana, no son vinculantes para el juzgador (aquel que está encargado del juicio oral), puesto que puede, si lo desea - de conformidad con el artículo 200 de su Código-, a pesar de haber sido aceptada la estipulación probatoria por el juez de la fase intermedia, disponer la presentación de los medios de prueba a ser actuados respecto al hecho sobre cuya realización existe acuerdo de las partes, lo cual a nuestro criterio desnaturaliza la esencia de esta institución procesal, abriéndose la posibilidad de que en el juicio oral se actúen medios de prueba no admitidos en la etapa intermedia en virtud de la estipulación probatoria presentada por las partes y aprobada por el juez o tribunal de control. ${ }^{11}$

\subsection{Colombia}

El proceso de reforma procesal penal en Colombia se inició gradualmente en el año 2005; a partir de entonces, se ha implementado paulatinamente el Código de Procedimientos Penales, promulgado por Ley 906

9 Tratadista venezolano.

10 Sentencia del Juzgado de Primera Instancia en lo Penal del Circuito Judicial Penal del Estado de Aragua, que acepta estipulación probatoria celebrada por las partes, durante el juicio oral y condena a acusado por delito de robo de vehículo automotor, 17 de febrero del 2010. <http://lara.tsj.gov.ve/decisiones/2010/ febrero/216-17-6M1082-09-.html>. [Consulta: 12 de enero del 2011.]

11 Juzgado de Investigación Preparatoria, en el caso peruano. 
en el 2004, cuyo artículo 356.4 se refiere a la figura procesal en estudio denominándola estipulación probatoria:

En desarrollo de la audiencia preparatoria el juez dispondrá:

$[\ldots]$

4. Que las partes manifiesten si tienen interés en hacer estipulaciones probatorias [...].

Se entiende por estipulaciones probatorias los acuerdos celebrados entre la Fiscalía y la defensa para aceptar como probados alguno o algunos de los hechos o circunstancias.

En Colombia, la estipulación probatoria es un acuerdo mediante el cual el fiscal y la defensa aceptan como probados determinados hechos, por lo que no resulta necesaria la actuación, en el juicio oral, de los medios de prueba que tengan por finalidad acreditarlos.

La oportunidad para plantear la estipulación probatoria es la audiencia preparatoria. A diferencia del código procesal venezolano, el Código de Procedimientos Penales colombiano no establece la notificación física de la acusación a las partes, sino prevé la realización de una audiencia denominada formulación de la acusación; es durante su desarrollo cuando el juez corre traslado a las demás partes del contenido de la acusación fiscal, que deben debatir en ese momento, privilegiando los principios de publicidad e inmediación postulados por el sistema acusatorio.

Con posterioridad a ese acto procesal debe realizarse la audiencia preparatoria, durante en la cual el juez tiene la obligación de preguntar a las partes si consideran conveniente presentar alguna estipulación probatoria respecto a los hechos $\mathrm{y}$, de resultar necesario, podrá disponer receso de una hora para la negociación y llegar a un acuerdo; al cabo de dicho término, las partes manifestarán si les ha sido posible arribar a un convenio y, de ser el caso, comunicarán al juez respecto a qué hecho. ${ }^{12}$ Estas estipulaciones se negocian y presentan oralmente durante la audiencia preparatoria.

12 Ver <http://www.unifr.ch/derechopenal/legislacion/co/LEY-0906-04_CPP colombia.pdf $>$. Asimismo, Consejo Superior de la Judicatura (2005). 
Otra diferencia respecto a la legislación procesal venezolana con relación a esta figura es que en Colombia se le otorga expresamente la facultad al juez para que exhorte a las partes a adoptar una estipulación probatoria, aun cuando estas no hayan expresado de manera espontánea su voluntad de hacerlo.

La legislación colombiana no establece de manera precisa en qué casos el acuerdo podría no ser aprobado por el juez; sin embargo, a tenor de lo resuelto en la casación 28212 por la Sala de Casación Penal de la Corte Suprema de Colombia, ${ }^{13}$ dicha desaprobación procedería solo cuando como consecuencia de la estipulación probatoria se vulneren derechos fundamentales.

Así se pronuncia la Sala Suprema al resolver un recurso de casación interpuesto por el fiscal contra la sentencia de segunda instancia, cuando en primera instancia se condenó al acusado como autor del delito de defraudación a los derechos patrimoniales de autor. La estipulación probatoria acordada por las partes estableció como hecho cierto lo consignado por el perito en su informe respecto a que los discos compactos hallados en poder del acusado durante su intervención eran discos no legales; ocurrió que durante la audiencia preparatoria, el juez aprobó la estipulación probatoria y por consiguiente el dictamen pericial no fue sometido a debate durante el juicio oral y el juzgado penal emitió fallo de primera instancia condenando al acusado. La defensa apeló el fallo argumentando que la conducta del sentenciado podía ser valorada como bagatela por la cantidad de discos compactos hallados en su poder, es decir, no discutió la ilegalidad del material, pues existía una estipulación probatoria que la daba por cierto.

Sometido el caso a conocimiento de la instancia superior, esta revocó la sentencia de primera instancia y absolvió al condenado, exponiendo como argumento que en el dictamen pericial - cuyo contenido fue aceptado como hecho cierto por las partes - se había llegado a la conclusión de la ilegalidad de los discos compactos únicamente por las características externas de impresión, fabricación, calidad y contenido impreso, pero no se estableció el contenido musical o videográfico, pues

13 Sentencia de la Corte Suprema de Colombia. Sala de Casación Penal, casa la sentencia impugnada que desconoció la estipulación probatoria celebrada entre las partes, 10 de octubre del 2007. <www.usergioarboleda.edu.co/derecho_penal/.../ jur_28212(10-10-07).doc>. [Consulta: 15 de enero del 2010.] 
la única manera de llegar a esa conclusión era escuchándolos o viéndolos. Desconociendo lo pactado entre las partes, la instancia superior revaloró el dictamen pericial en sentido contrario a lo estipulado por ellas.

En su pronunciamiento, la Sala Penal Suprema casó la sentencia de segunda instancia y estableció que el juzgador debe dar por ciertos los hechos y circunstancias sustentados en un acuerdo o pacto por las partes, en los precisos términos pactados entre aquellos, como claro desarrollo de los postulados de eficiencia y celeridad propios de dicho modelo, siempre y cuando no advierta violación de un derecho fundamental.

\subsection{Chile}

El Código Procesal Penal de Chile, promulgado el 12 de octubre del 2000, refiere al tema bajo análisis denominándolo convenciones probatorias en su artículo 275 :

Art. 275.- Convenciones probatorias. Durante la audiencia, el fiscal, el querellante, si lo hubiere, y el imputado podrán solicitar en conjunto al juez de garantía que dé por acreditados ciertos hechos, que no podrán ser discutidos en el juicio oral. El juez de garantía podrá formular proposiciones a los intervinientes sobre la materia.

Si la solicitud no mereciere reparos, por conformarse a las alegaciones que hubieren hecho los intervinientes, el juez de garantía indicará en el auto de apertura del juicio oral los hechos que se dieren por acreditados, a los cuales deberá estarse durante el juicio oral.

Según la legislación procesal penal chilena, si bien las partes en conjunto son las llamadas a presentar y solicitar que se den por aprobadas las convenciones probatorias durante la audiencia de preparación del juicio oral (audiencia preliminar en otras legislaciones, como la peruana), también es posible que sea el juez quien les proponga la posibilidad de arribar a una convención probatoria; es decir, se otorga al juez la posibilidad de proponer a las partes arribar a acuerdos sobre hechos (si advierte la posibilidad de hacerlo) si ellas de manera espontánea no lo han solicitado. 
Esto no faculta al juez a que de manera unilateral pueda establecer que tal o cual hecho no requerirá ser probado en el juicio oral; son las partes las facultadas a acordar. El juez sólo se limitará a proponerles que lleguen a una convención probatoria, pues determinado hecho es aceptado por ambas; sin embargo, si después de acceder a la propuesta realizada por el juez, las partes no logran arribar a un acuerdo, no será posible - de oficio- establecer una convención probatoria, por falta de acuerdo de las partes para celebrarla.

Las convenciones probatorias en Chile no requieren ser presentadas por escrito - como de manera expresa lo señala el CPP04-, sino de forma oral, lo que es congruente con el principio de oralidad recogido por el sistema acusatorio.

Los acuerdos a los que lleguen las partes para tener por acreditados ciertos hechos - ya sea por iniciativa propia o a propuesta del juez-, deben ser sometidos a control y aprobación del juez; de aprobarlos, indicará expresamente en el auto de inicio del juicio oral los hechos materia de convención probatoria, los que en consecuencia no serán probados durante el juicio oral.

\section{Tratamiento legislativo en el Perú}

\subsection{Ubicación sistemática y regulación}

Actualmente, en el Perú coexisten tres legislaciones procesales penales, debido a que la reforma procesal penal aún no ha sido implementada en todos los distritos judiciales. ${ }^{14}$ En aquellos distritos judiciales en los que aún no rige el CPP04, el proceso se encuentra regulado tanto por disposiciones contenidas en el Código de Procedimientos Penales de 1940 -inspirado en el sistema inquisitivo- como por el Código Procesal

14 Para efectos de la administración de justicia, el Perú ha sido dividido en 29 distritos judiciales, 16 de los cuales aplican íntegramente el CPP04; solo algunas de sus disposiciones se aplican a todos los distritos judiciales. Se prevé que la implementación total del CPP04 se alcanzará en el 2013. Según la Ley 29574 -publicada el 17 de setiembre del 2011 - y la Ley 29648 - del 1 de enero del 2011-, la vigencia del CPP04 solo rige para delitos contra la Administración Pública a partir del 15 de enero del 2011, en el distrito judicial de Lima, y del 1 de abril del mismo año en los distritos judiciales del Lima Norte, Lima Sur y Callao. En el resto de los 9 distritos judiciales rige a partir del 1 de junio del 2011. 
Penal de 1991 - primer intento de reforma- y algunos artículos del CPP04 declarados vigentes a nivel nacional.

Tanto el Código de Procedimientos Penales de 1940 como el Código Procesal Penal de 1991 no contienen dentro de sus disposiciones la convención probatoria; por ello, se trata de una figura procesal novedosa, introducida a nuestro ordenamiento con el CPP04, que faculta a las partes a negociar respecto al objeto de las convenciones probatorias.

Con relación a esta figura, el CPP04, en sus artículos 156.3 y 350.2, prescribe:

Art. 156.- Objeto de prueba.

3. Las partes podrán acordar que determinada circunstancia no necesita ser probada, en cuyo caso se valorará como un hecho notorio. El acuerdo se hará constar en el acta.

Art. 350.- Notificación de la acusación y objeción de los demás sujetos procesales.

2. Los demás sujetos procesales podrán proponer los hechos que aceptan y que el juez dará por acreditados, obviando su actuación probatoria en el juicio. Asimismo, podrán proponer acuerdos acerca de los medios de prueba que serán necesarios para que determinados hechos se estimen probados. El juez, sin embargo, exponiendo los motivos que lo justifiquen, podrá desvincularse de esos acuerdos; en caso contrario, si no fundamenta especialmente las razones de su rechazo, carecerá de efecto la resolución que los desestime (el subrayado es nuestro).

Si bien en estos artículos no se hace mención expresa a la denominación en estudio, en los artículos 352.6 y 353.2 del CPP04 sí se hace referencia a la denominación convenciones probatorias:

Artículo 352.

$[\ldots]$

6.- La resolución sobre las convenciones probatorias, conforme a lo dispuesto en el numeral 2) del artículo 350, no es recurrible. En el auto de enjuiciamiento se indicarán los hechos específicos que se dieren por acreditados o los medios de prueba necesarios para considerarlos probados (el subrayado es nuestro). 
Artículo 353.

$[\ldots]$

2. El auto de enjuiciamiento deberá indicar, bajo sanción de nulidad:

[...]

c) Los medios de prueba admitidos y, de ser el caso, el ámbito de las convenciones probatorias, de conformidad con el numeral 6) del artículo anterior (el subrayado es nuestro).

La regulación de este instituto procesal penal en el CPP04 se encuentra ubicada dentro de las disposiciones referidas a la etapa intermedia del proceso penal, antes de la regulación del juicio oral, coincidiendo con la finalidad de las convenciones probatorias, que es facilitar el juicio oral.

A diferencia de Chile y Colombia, en el Perú - como en Venezuela el CPP04 exige la presentación de convenciones probatorias por escrito, dentro de los diez días posteriores a la notificación de la acusación fiscal, cuando los hechos objeto de acusación y los medios de prueba con los que cuenta el Ministerio Público para sostener su teoría del caso se han establecido de manera definitiva. Esa presentación escrita debe entenderse como la expresión de voluntad de cada una de las partes de arribar, con la otra, a un acuerdo.

\subsection{Objeto de las convenciones probatorias}

Según lo legislado por el CPP04, en el Perú pueden ser objeto de convenciones probatorias no solo los hechos, sino los medios de prueba, posibilidad no contemplada en las otras legislaciones revisadas en este trabajo.

\subsubsection{Convenciones probatorias sobre hechos}

En este caso, una de las partes afirma un hecho o circunstancia $^{15}$ no controvertido por la otra, sobre el cual hay consenso de las partes en que no necesita ser probado y así lo solicitan al juez.

15 “Las circunstancias del delito son acontecimientos que están presentes en la comisión del delito, que sin modificar la naturaleza del mismo influyen en la punibilidad, ya sea agravándola o atenuándola" (Quisbert s/f). 
Por ejemplo, en un caso de homicidio, la Fiscalía expone como teoría del caso:

- Hecho 1: El día del suceso, el acusado ingresó a la casa de la víctima a las 22:00 horas.

- Hecho 2: El acusado dio muerte a la víctima de un golpe en la cabeza.

Por su parte, la defensa esboza como teoría del caso:

- Hecho 1: El día del suceso el acusado ingresó a la casa de la víctima a las 22:00 horas.

- Hecho 2: El acusado discutió con la víctima.

- Hecho 3: El acusado salió por la puerta trasera.

- Hecho 4: Cuando el acusado se retiró de la casa de la víctima, esta se encontraba con vida e ilesa.

Durante la etapa de investigación, las partes no llegan a un acuerdo que evite el juicio oral y la Fiscalía formaliza acusación en contra del acusado. Pero respecto al hecho $1-\mathrm{el}$ acusado ingresó al domicilio de la víctima a las 22:00 horas-, y con miras a facilitar el juicio, la defensa y la Fiscalía pueden arribar a una convención probatoria y evitar que durante el juicio oral aquel hecho sea materia de prueba.

$\mathrm{Al}$ no haber consenso respecto a los hechos del 2 al 4 y demás circunstancias planteadas por la Fiscalía y la defensa, no alcanzan a ser materia de convención probatoria, por lo que deberán ser objeto de prueba durante el juicio oral.

En ese caso el juez dará por cierto el hecho 1, materia de la convención probatoria - si lo considera pertinente ${ }^{16}-$, el que no será objeto de debate en el juicio oral.

En virtud del artículo $156.3,{ }^{17}$ el hecho no controvertido adquiere la condición de hecho notorio, el cual, junto con los principios de la lógica,

$16 \mathrm{El}$ juez, en virtud del CPP04, puede desligarse de las convenciones probatorias acordadas por las partes; para ello, es requisito de validez que exponga los fundamentos de su decisión; de no encontrarse debidamente fundamentado el rechazo, su decisión carecerá de objeto. Debe entenderse, entonces, que sólo bajo esta condición tendrá lugar el reexamen de esta decisión por el juez o colegiado a cargo del juicio oral.

17 "Las partes podrán acordar que determinada circunstancia no necesita ser probada, en cuyo caso se valorará como un hecho notorio. El acuerdo se hará constar en el acta". 
las máximas de la experiencia y los conocimientos científicos, ${ }^{18}$ no necesita ser actuado. ${ }^{19}$

Así lo señala el reconocido procesalista peruano César San Martín Castro:

[...] lo notorio significa lo evidente e incontrovertible; la sola percepción del hecho en sí lo revela como cierto e indiscutible [...] los hechos notorios no necesitan prueba, puesto que solo constituyen objeto de prueba los hechos que puedan dar lugar a duda [...] si un hombre se mueve, habla, etc., no hace falta pruebas para demostrar que está vivo; si se encuentra un cuerpo humano putrefacto, ni un filósofo siquiera podría poner en duda que se trata de un cadáver. ${ }^{20}$

El consenso acerca de un hecho o determinada circunstancia (tiempo, lugar o modo en que ocurrió el hecho) significa que no tiene carácter controvertido y, por tanto, no amerita debate ni da lugar a duda. De ahí que un hecho no controvertido no necesita ser comprobado y, por lo mismo, no constituye objeto de prueba susceptible de ser debatido en el juicio oral.

Se discute la equiparación del hecho objeto de convención probatoria a un hecho notorio, pues podría constituir una vulneración de la libre valoración de la prueba otorgada al juez. Al respecto, se sostiene lo siguiente: si ni siquiera la ley le dice al juez qué valor brindarle a las pruebas, ¡cómo las partes van a hacerlo!; ¿por qué el juez tiene que otorgarle a un hecho la calidad de hecho notorio?; ¿basado sólo en que las partes se encuentran de acuerdo respecto a su realización? Como contraparte, puede sostenerse que no existe vulneración de la libre valoración de la prueba, pues el hecho sobre el cual hay consenso no va a ser probado; en consecuencia, no existen pruebas que valorar. La discusión

18 Si bien el inciso 2 del artículo 393 del CPP04 está normado en la etapa de la deliberación, apreciación y valoración de la prueba, no deja de tener directa relación con lo aquí señalado, pues esta norma indica: "La valoración probatoria respetará las reglas de la sana crítica, especialmente conforme a los principios de la lógica, las máximas de la experiencia y los conocimientos científicos".

19 Ver Mixán Mass (1992: 186-197). Así también lo establece el CPP04 en el artículo 156.2: “No son objeto de prueba las máximas de la experiencia, las leyes naturales, la norma. jurídica interna vigente, aquello que es objeto de cosa juzgada, lo imposible y lo notorio".

20 Manzini, citado por San Martín Castro (2003: I, 60). 
sobre este tema podría ser compleja; sin embargo, según nuestro criterio, no existe vulneración de la libre valoración de la prueba, porque esta valoración solo tiene lugar una vez concluido el juicio oral y sobre las pruebas actuadas durante su realización, más aun cuando existe control judicial sobre el contenido de las convenciones probatorias. Si el juez estima que los medios de prueba relacionados con el hecho acordado no controvertido por las partes deben ser actuados y valorados, puede desvincularse del acuerdo o no aprobarlo.

Como ejemplo real de una convención probatoria practicada en el Perú, citemos un caso rescatado de nuestra revisión de diversos autos de enjuiciamiento. ${ }^{21}$

Se trata de una acusación por delito de violación de la libertad sexual en la modalidad de violación de persona en incapacidad de resistir. Los hechos ocurrieron en el distrito de Barranca, jurisdicción del distrito judicial de Huaura, pionero en la aplicación del CPP04. Se atribuye al acusado haber hecho sufrir el acto sexual a la agraviada -invidente, con retardo mental moderado- entre mayo, junio y julio del 2008, aprovechando su condición de cuñado y persona de confianza, mediante violencia y amenaza. Como consecuencia de las violaciones de las que fue objeto, la agraviada ha alumbrado un bebé.

Formulada oralmente la acusación de la Fiscalía, la defensa no controvierte la relación de filiación entre el acusado y el menor, hijo de la víctima, mas sí refuta que las relaciones entre ellos hayan sido consecuencia de actos de violación. Ante este panorama, la defensa propone que se tenga por acreditada la paternidad del imputado sobre el menor (hecho sostenido por la Fiscalía y aceptado por la defensa), propuesta que es aceptada por el fiscal y aprobada por el juez. En consecuencia, no es razonable que los medios de prueba ofrecidos por el fiscal con la finalidad de probar dicha paternidad - esto es, la declaración de los médicos biólogos que participaron en la toma de muestras de ADN y la declaración de los biólogos que realizaron el examen de ADN - sean actuados en el juicio oral correspondiente - en virtud de la convención

21 Auto de enjuiciamiento emitido por el Juzgado de Investigación Preparatoria de Barranca (distrito ubicado aproximadamente a $194 \mathrm{~km}$ al norte de la capital peruana), de 15 de enero del 2010, en el expediente 016-2009-35. Si bien la convención probatoria consta en el acta de enjuiciamiento, fue presentada durante la realización de la audiencia preliminar que tuvo lugar antes de la emisión del auto de enjuiciamiento. 
probatoria acordada entre las partes-, pues corresponde considerarla como un hecho probado, conclusión a la que arriba el juez al aprobar el acuerdo de las partes.

\subsubsection{Convenciones probatorias sobre medios de prueba}

En ocasiones ocurre que para un determinado hecho - objeto de prueba en el juicio oral - existe más de un medio de prueba cuya finalidad es acreditarlo; en esos casos, las partes - fiscal y abogado defensor- pueden acordar la actuación de solo uno de ellos. De esa manera, el juicio oral no se prolongará por la actuación de medios de prueba que tengan la misma finalidad.

Así por ejemplo, en un caso de homicidio, la Fiscalía presenta como medios de prueba el testimonio de dos testigos que lo presenciaron y el examen del perito químico que practicó la prueba de absorción atómica realizada en las manos y vestimenta que portó el acusado el día de los hechos (además del informe pericial, claro está), para demostrar que fue este el autor del disparo mortal contra la víctima.

Como se nota, los tres medios de prueba ofrecidos tienen la misma finalidad: acreditar que fue el acusado quien realizó el disparo que mató al agraviado. La defensa y la Fiscalía podrían llegar a acordar que se acreditará tal hecho sólo con el examen del perito químico - y entonces la valoración de este medio de prueba será determinante para acreditar el hecho-, de manera que el fiscal ofrezca como prueba pericial dicho informe.

Con una convención probatoria de esta naturaleza se busca facilitar el debate actuando únicamente uno de los medios de prueba ofrecidos para acreditar el hecho, debiendo el juez - en virtud de la convención arribada por las partes - tener por admitido sólo aquel acordado por los sujetos procesales para que se actúe y debata en el juicio oral.

Cuando las partes optan por convenir que solo un medio de prueba de todos los presentados para acreditar un hecho será actuado en juicio oral, los demás - en virtud de la estipulación probatoria - quedan descartados y, por tanto, no serán valorados por el órgano jurisdiccional. Es justamente ello lo que convierte en compleja esta clase de convención, pues la parte que aporta los medios de prueba - que luego no serán admitidos debido a la aprobación de la convención probatoria - debe tener la capacidad de poder determinar cuál de todos sus medios resulta más idóneo para acreditar el hecho, pues podría, a raíz de la conven- 
ción arribada, ser precisamente ese medio idóneo el que no fuese actuado en el juicio, favoreciendo esta circunstancia a la contraparte. La elección del medio de prueba que se actuará en el juicio oral se convierte, entonces, en una decisión estratégica.

La convención probatoria sobre medio de prueba no ha sido normada en las legislaciones de los otros países a los que nos hemos referido en este estudio.

En el Perú se otorga a las partes la posibilidad de arribar a acuerdos mediante los cuales puedan decidir la actuación o no actuación de medios de prueba durante el juicio oral.

\subsection{Control judicial}

Es el juez quien debe preservar la legalidad de los acuerdos y puede desvincularse válidamente de las convenciones probatorias. Y si bien el código no especifica las razones por las cuales se le permite desvincularse de estos acuerdos, no obstante, si seguimos una interpretación sistemática con las otras normas procesales, puede colegirse que será cuando afecten derechos fundamentales o trasgredan los principios de la lógica, las máximas de la experiencia o los principios científicos. ${ }^{22}$

La no afectación de la teoría del caso de una de las partes ${ }^{23}$ no debiera ser un aspecto objeto de control por el juez de investigación preparatoria. Bajo los cánones del sistema acusatorio, corresponde a cada una de las partes preservar la versión de los hechos sobre la cual ejercen y

22 Por ejemplo, el juez advierte que si bien la Fiscalía y la defensa coinciden sobre el medio empleado para el asesinato, acordando que fue la pistola encontrada en el lugar de los hechos, puede darse el caso de que a partir de otros medios de prueba (pericial, testimonial) esto resulte imposible o de difícil realización, como cuando el diámetro de la herida encontrada en el cadáver no guarda ninguna relación con el cañón de la pistola hallada.

23 En un caso hipotético, el juez podría advertir que el imputado no pudo, por intermedio de su abogado, investigar sobre una prueba con la misma exhaustividad que el fiscal, razón por la cual, de aceptarse la estipulación, lo colocaría en desventaja y se vulneraría el principio de igualdad de armas: "[...] a la parte que no tuvo la posibilidad (por ausencia de medios económicos, técnicos, científicos, etc.) de adelantar en forma exhaustiva la investigación, le conviene no estipular para no atar o limitar la teoría del caso [...]" (Silva Corredor 2005: 151). 
estructuran su estrategia; no le corresponde al juez suplir la deficiencia de las partes, mas aún cuando no es obligación de estas arribar a una convención probatoria, sino que es una decisión estratégica en la que el juez no debe tener injerencia, salvo que - como acotamos - vulnere derechos fundamentales de una de las partes.

En virtud del control que ejerza el juez del contenido de la convención probatoria, se le otorga la prerrogativa de desvincularse de esta. Sin embargo, por respeto al debido proceso, deberá motivar su resolución, bajo sanción de ineficacia (inciso 2 in fine del artículo 350 del CPP04), allanando el camino a las partes para solicitar su reexamen por el juez penal o juzgado colegiado encargado del juicio oral.

\section{Aplicación práctica de las convenciones probatorias en el Perú}

En congruencia con el sistema acusatorio, el CPP04 ha incorporado una serie de instituciones de justicia negociada. Si bien todas, al igual que las convenciones probatorias, resultan novedosas en el país y, por ende, de complicada aplicación por la falta de práctica, en negociación, de fiscales, abogados, imputados y demás involucrados, en los informes emitidos a raíz de la puesta en aplicación del CPP04 en once distritos judiciales $^{24}$ (Huaura, La Libertad, Tacna, Moquegua, Arequipa, Tumbes, Piura, Lambayeque, Cusco, Puno y Madre de Dios ${ }^{25}$ ) se da cuenta de que en la práctica cotidiana los actores procesales se encuentran familiarizados con su uso y los porcentajes de aplicación se encuentran en franco incremento, habiéndose concluido un porcentaje mayoritario de los casos sin juicio oral, debido a la aplicación de las salidas alternativas.

Sin embargo, a pesar de los beneficios que las convenciones probatorias aportan en cuanto a economía, celeridad y eficiencia procesal al juicio oral, en la práctica no existe reporte que evidencie su aplicación, ni siquiera de manera aislada, y tampoco fue posible acceder a información documentada al respecto. Ello nos permitió concluir a priori su no utilización como mecanismo que simplifique el juicio oral. De esta

24 Si bien, en el Perú, el CPP se encuentra vigente en 16 distritos judiciales, a la fecha solo 11 de ellos han emitido informes, en los que no se hace mención a las convenciones probatorias. Para mayor información, consultar $<\mathrm{http}: / /$ historico. pj.gob.pe/CorteSuprema/ncpp/index.asp?opcion=informes>.

25 Se ha tenido acceso a los informes emitidos por Tumbes, Lambayeque, La Libertad, Huaura, Arequipa, Moquegua, Tacna y Ayacucho. 
manera, y con la finalidad de documentar dicha aseveración, iniciamos la búsqueda de actas de audiencias preliminares, en donde se discutieran convenciones probatorias planteadas por las partes, pero no pudo obtenerse mucho material de ese tipo (salvo el auto de enjuiciamiento mencionado en el presente estudio ${ }^{26}$ ).

Por resultar insuficiente la información hallada, decidimos realizar una encuesta - no representativa - a jueces, fiscales y abogados a título de ejemplo, que nos permitiera tomar conocimiento directo de las razones por las cuales, en la práctica, las convenciones probatorias son las instituciones de justicia negociada con menor índice de aplicación y no están cumpliendo con su función de simplificar el juicio oral. La muestra a la que se aplicó dicha encuesta se encuentra representada en el gráfico 1:

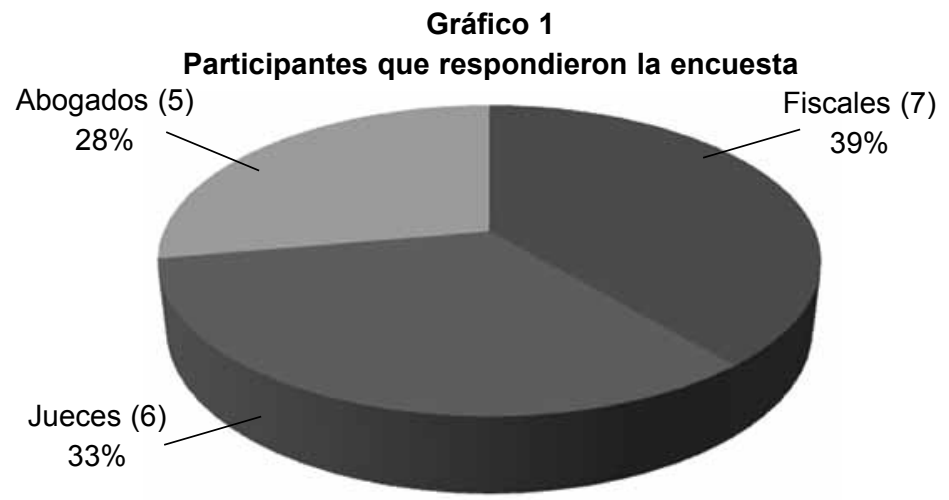

Fuente: Encuesta. Elaboración propia.

Nuestro universo estuvo constituido por dieciocho personas 27 $(100 \%)$, siete de las cuales son fiscales $(39 \%)$, cinco son abogados $(28 \%)$ y seis son jueces (33\%).

26 Punto 5.2.1.

27 Que laboran en los distritos judiciales de Arequipa, Huaura, Huaral, La Libertad, Lambayeque, Lima, Moquegua, Piura, Tacna, Cusco; ellas respondieron una encuesta entre el 4 de noviembre del 2010 al 31 de enero del 2011. Dichas personas fueron: Giammpol Taboada Pilco (juez de Investigación Preparatoria en Trujillo, departamento de La Libertad), Juan Carlos Checkley Soria (juez superior Penal de Apelaciones en Piura), Víctor Burgos Mariños (juez superior en La Libertad), José Cabrejo Villegas (juez superior de Apelaciones en La Libertad), 
La encuesta se inició con una interrogante genérica respecto a los mecanismos de justicia negociada legislados por el CPP04: se les preguntó si consideraban que estos contribuyen de manera efectiva a solucionar los conflictos penales. Las respuestas se muestran en el gráfico 2:

\section{Gráfico 2}

¿La justicia negociada contribuye a la solución de los conflictos penales?

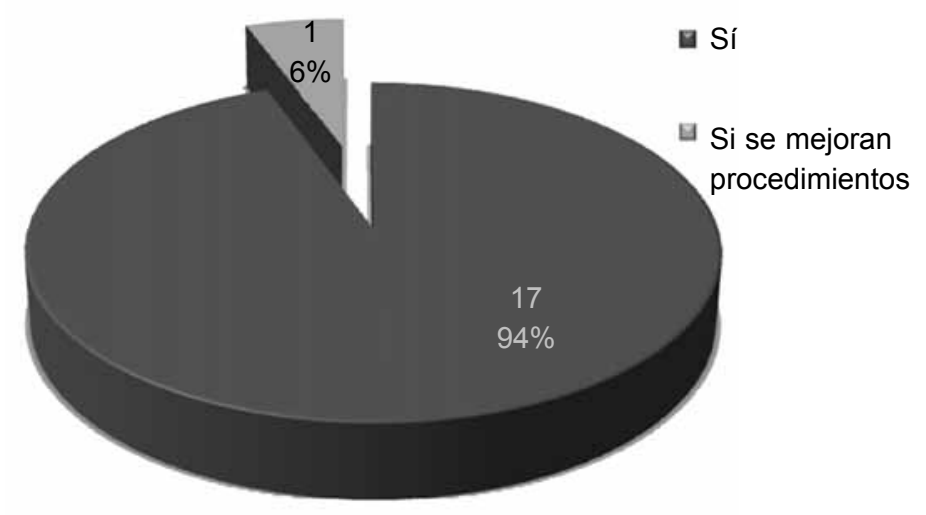

Fuente: Encuesta. Elaboración propia.

Como se observa en el gráfico 2, diecisiete de los dieciocho participantes respondieron afirmativamente, esto es, consideraron que los mecanismos de justicia negociada contribuyen en forma positiva a la solución de los conflictos penales: facilitan el término de casos, reducen el tiempo de tramitación, aumentan los niveles de satisfacción de los intervinientes, evitan o disminuyen la victimización secundaria, contri-

Frezia Sissi Villavicencio Ríos (juez de Investigación Preparatoria en Huaura), Edhin Campos Barranzuela (juez superior en Talara, departamento de Piura), Liliana Calderón Jacinto (abogada defensora en Lima), Miguel Falla Rosado (abogado defensor en Lambayeque), Jimmy Junco Zorrilla (abogado defensor en Tacna), Orestes Zegarra Zevallos (abogado defensor en Arequipa), Robert Chávez Hurtado (abogado defensor de oficio en Cusco), Feliciano Lalupú Sernaqué (fiscal provincial en Tacna), Alcides Chinchay Castillo (exfiscal provincial de Huaral), Patricia Rabines Briceño (fiscal provincial en La Libertad), Eder Farfán Romero (fiscal provincial en Moquegua), Lourdes Rejas Mejía (fiscal de Investigacion Preparatoria en Tacna), Juan Hurtado Poma (fiscal Provincial en Huaura) y Yael López Gamboa (fiscal provincial en La Libertad). 
buyen a la funcionalidad del sistema y a la descarga procesal, otorgan rapidez al proceso penal, humanizan el proceso, etc.

Solo uno de los encuestados (abogado) consideró que las instituciones de justicia negociada no cumplen con su función, que se requiere mejorar sus disposiciones para su efectiva aplicación y cumplimiento, y propuso - a manera de ejemplo - ampliar el término para la aplicación del principio de oportunidad. ${ }^{28}$

La siguiente pregunta de la encuesta estuvo referida a la experiencia de los participantes en negociaciones con su contraparte: se les solicitó señalar a qué figura de justicia negociada habían recurrido más. Las respuestas se muestran en el gráfico 3:

Gráfico 3

¿Cuál es la figura de justicia negociada que más ha utilizado?

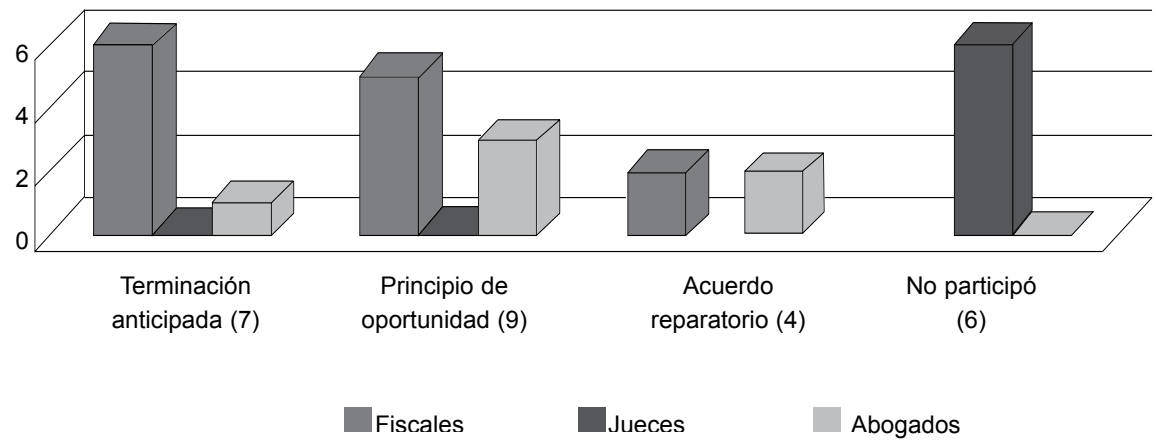

Fuente: Encuesta. Elaboración propia.

De la información contenida en el gráfico $3^{29}$ se aprecia que la figura que más aplicaron nuestros encuestados es el principio de oportunidad (9 de 18), la terminación anticipada ocupa el segundo lugar, y los acuerdos reparatorios el último. Seis de los encuestados manifestaron no haber participado en ninguna negociación: se trata de los jueces, quie-

28 El CPP04 establece que el principio de oportunidad puede aplicarse hasta antes de formularse acusación. (artículo 2.7).

29 En este gráfico se consigna más de una respuesta por participante, debido a lo cual el total resulta superior al número de encuestados. 
nes, por la naturaleza de su labor durante la investigación y el juicio oral, no les compete negociar con las partes; sin embargo, refirieron haber intervenido para propiciar la negociación.

La encuesta continuó indagando, esta vez sobre la participación en alguna convención probatoria para facilitar el juicio. Las respuestas se muestran en el gráfico 4 :

\section{Gráfico 4}

¿Ha participado de una convención probatoria?

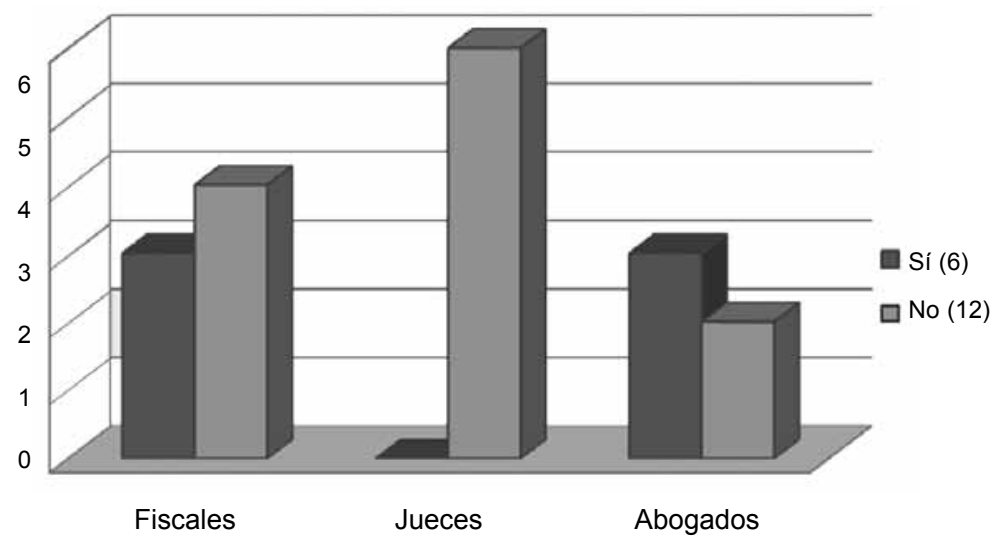

Fuente: Encuesta. Elaboración propia.

Del gráfico surge que seis de nuestros encuestados (tres abogados y tres fiscales) refieren haber participado en una convención probatoria, dos abogados aún no han tenido experiencia con esta figura procesal, y tampoco la han tenido cuatro fiscales. Por su parte, los jueces, por su labor, manifestaron no haber participado de convenciones probatorias. Tampoco refieren haber aprobado alguna presentada por las partes.

Luego se preguntó a los encuestados acerca de las causas por las cuales las convenciones probatorias no se aplican habitualmente. Las respuestas se pueden graficar así: 
Gráfico 5

¿A qué atribuye la escasa aplicación de las convenciones probatorias?

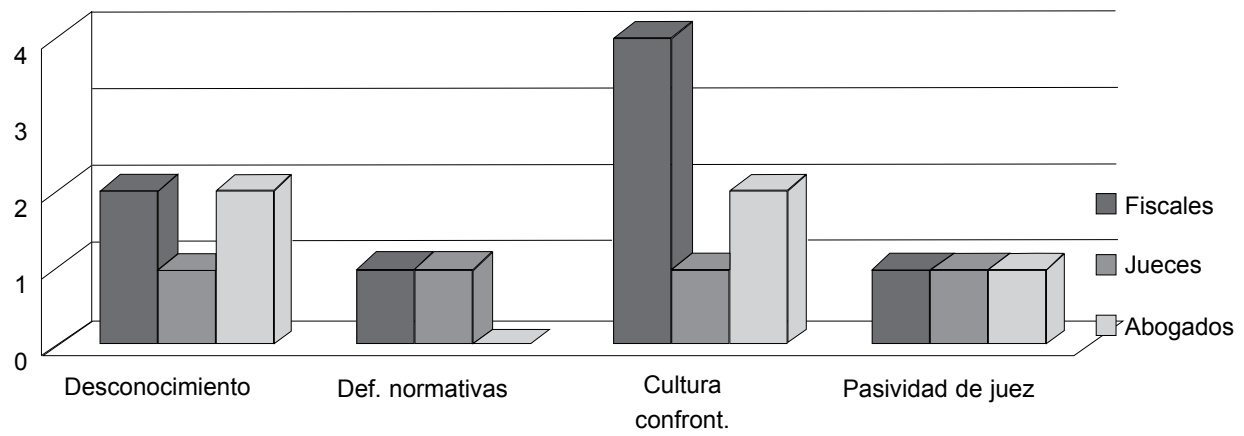

Fuente: Encuesta. Elaboración propia.

De las respuestas representadas en el gráfico 5 se concluye que, a criterio de los encuestados, las principales causas de la poca aplicación de la convención probatoria son:

- Desconocimiento de la figura por parte de los aplicadores de justicia.

- Deficiencias normativas: poco desarrollo normativo, momento inadecuado para su postulación, plazo insuficiente y presentación por escrito.

- Cultura confrontacional de abogados y fiscales: las partes no consideran útil la figura o creen que siempre una de las partes va a perder.

- Rol pasivo del juez en la etapa intermedia.

Para los fiscales encuestados, la principal causa de la poca aplicación de las convenciones probatorias es la cultura confrontacional, todavía presente en nuestra administración de justicia penal. Por su parte, los jueces consideran que el desconocimiento de la figura por parte de los abogados y fiscales es la causa principal, mientras que los abogados atribuyen igual importancia tanto al desconocimiento de la figura como al rol pasivo de los jueces, probablemente porque consideran que el desconocimiento de las partes debe ser suplido por los jueces. Por último, mientras que ningún abogado atribuyó la poca aplicación de la figura a las deficiencias normativas, jueces, abogados y fiscales coinci- 
den en atribuirla a la pasividad de los jueces para propiciar la postulación de convenciones probatorias.

A partir de las respuestas obtenidas, hemos reunido las causas que dificultan la aplicación de esta institución procesal penal en dos grandes grupos: normativas y culturales. De su desarrollo nos ocuparemos de aquí en adelante, incluyendo propuestas de mejora, algunas de las cuales han sido proporcionadas por los encuestados.

\subsection{Causas normativas}

a) No existe desarrollo normativo de esta institución procesal penal.

La norma procesal penal no se ha ocupado en especial de esta figura. El CPP04 no desarrolla la figura procesal en un título, capítulo o sección, ni tampoco contiene un artículo independiente al que titule con su nombre, como sí ocurre con la terminación anticipada $^{30}$ o el principio de oportunidad. ${ }^{31}$

El artículo 350.2, si bien define la convención probatoria, no se refiere a su nombre; la describe, mas no la denomina. El nombre convenciones probatorias lo encontramos en artículos posteriores (352.6 y 353.2.c), que hacen referencia a esta figura procesal penal, pero no de manera independiente; ello impide su rápida identificación, es decir, su denominación y desarrollo (concepto, ámbito, modalidades, control judicial, plazo, etc.) se encuentran previstos en artículos distintos, lo cual conlleva la dificultad de ser comprendida mediante la sola lectura de una sección, capítulo o título. Ello, definitivamente, contribuye a su desconocimiento.

Esta situación resultó evidente apenas iniciado el trabajo de campo; pudimos constatar - durante el recojo de informaciónla ignorancia de la figura, incluso entre algunos de los encuestados, lo que llevó a incluir un pie de página en la encuesta, definiéndola.

Así pues, si pretendemos su conocimiento y el incremento de su aplicación, será necesario realizar una modificación normativa que desarrolle este instituto procesal penal en un capítulo inde-

30 Legislada en el título V del CPP04, que tiene el nombre de la figura procesal penal y comprende los artículos 468 a 471 .

31 Esta figura procesal penal ha sido desarrollada in extenso en el artículo 2 del CPP04. 
pendiente, titulado con el nombre de la figura, para facilitar su rápida identificación y conocimiento por parte de los actores procesales.

b) Al momento de la postulación de las convenciones probatorias, la defensa todavía no ha hecho pública su teoría del caso, lo cual pone a la Fiscalía en una posición de desventaja para negociar.

Según el CPP04, las convenciones probatorias deben ser planteadas al absolver el traslado de la acusación; se cree que para ese momento procesal la defensa puede identificar cuál es la teoría del caso de la Fiscalía - pues se deduce de la acusación-. Sin embargo, esta aún no conoce los medios de prueba que serán presentados por la defensa ni puede presumir, fundadamente, cuál es su teoría del caso. Esto genera una posición de ventaja de la defensa en el momento de negociar la posibilidad de una convención probatoria.

Esta afirmación resulta hasta cierto grado cuestionable; el fiscal, al hacer la narración de los hechos que imputa al acusado y ofrecer los medios de prueba que se actuarán en juicio, no necesariamente expone su teoría del caso. En la imputación contenida en su acusación, el fiscal puede señalar, por ejemplo: "Se atribuye a Tomás Guizado haber hecho sufrir a Dolores Campos el acto sexual mediante violencia y amenaza, en diversas oportunidades, hechos que han tenido lugar en el propio domicilio de la víctima, en circunstancias en que se encontraba sola". Como medios de prueba ofrece el testimonio de la agraviada, la prueba pericial psicológica, el examen del perito que practicó la prueba, los testimonios de los familiares de la víctima, entre otros medios; sin embargo, aun cuando la acusación contenga toda esa información, el fiscal no ha expuesto su teoría del caso: sólo se ha limitado a narrar los hechos, mas no ha dado su versión de cómo sucedieron (teoría del caso); por ejemplo: por qué la víctima toleró los abusos, máxime si fácilmente podría advertirse como teoría del caso de la defensa un asunto de sexo consentido.

La Fiscalía debe elaborar su teoría del caso explicando todos y cada uno de los hechos, pero no necesariamente en la acusación, en la cual basta la imputación contra el acusado, lo que dista mucho de la teoría del caso: esta será develada en la audiencia preliminar, para sustentar la pertinencia de los medios de prueba, 
o durante los alegatos de inicio, en el juicio oral. En consecuencia, la acusación fiscal no significa exposición de teoría del caso de la Fiscalía; por ende, sostener que hay una posición desventajosa para negociar una convención probatoria en ese momento, no es del todo cierto, pues ni la Fiscalía ni la defensa han expuesto aún su teoría del caso; ambas se encuentran en igualdad de condiciones.

Ante la creencia de la posición de desventaja en que pudiera encontrarse la Fiscalía, se expone la necesidad de implementar la obligación de descubrimiento de medios de prueba para la defensa; existe esa obligación solo para la Fiscalía y por ello se asume nuevamente ventajas para la defensa.

Para entender este punto y determinar si es en verdad necesario imponer a la defensa la obligación de descubrir los medios de prueba con los que cuente, debemos referirnos a la figura del "descubrimiento de pruebas". Esta figura, conocida como discover, ${ }^{32}$ tiene cabida en los sistemas adversariales, ${ }^{33}$ que conci-

32 El discovery and inspection - como se suele denominar técnicamente- es una actividad preliminar al juicio, en la que los abogados y fiscales ejecutan la función colectora de pruebas, antes de producirse el trial (juicio o proceso). Una parte puede solicitar al contrario la exhibición para su inspección de prueba documental, o que comparezca a un interrogatorio previo, como también tomar declaración a testigos en forma extrajudicial. "La actividad probatoria preliminar. ¿Sería necesaria su regulación?". <http://www.tipete.com/userpost/monografiasy-apuntes/prueba-preliminar-derecho>. [Consulta: 17 de febrero del 2011.]

33 Al respecto, el profesor español José María Asencio Mellado, durante una entrevista publicada por Alerta Informativa en junio del 2008, respecto al modelo al que corresponde el CPP04, señaló: “Es un modelo acusatorio, entendiendo por tal uno basado en los principios que parten de considerar el delito como un fenómeno público e indisponible, con tribunales imparciales, pero con las facultades obvias derivadas del principio de aportación y contradictorio, es decir, con pleno respeto al derecho de defensa. Toda referencia al modelo adversarial es una imprecisión o una errónea calificación de un sistema, como el acusatorio, que se quiere identificar con elementos contrapuestos al primero. No hay adversarial cuando el delito es un fenómeno público que, por ello, tiene un interés de la misma naturaleza. El adversarial hunde sus raíces en un sistema penal privado en el que el conflicto era de la misma naturaleza, en el que las partes combatían con absoluta igualdad de armas y el juez no intervenía, pues el Estado y la sociedad carecían de interés. El acusatorio parte de considerar el delito como fenómeno público y, por tanto, con intereses de la misma naturaleza - aunque 
ben el papel del fiscal como enfocado en la búsqueda de evidencias destinadas a desvirtuar la presunción de inocencia del imputado: no está obligado a recabar evidencias liberadoras de responsabilidad penal, empero se encuentra en la obligación de ponerlas a disposición de la defensa en caso de encontrarlas. Ante la liberación del deber de recolección de medios de prueba exculpatorios a cargo de la Fiscalía, se le atribuye a la defensa la facultad de recaudarlos por cuenta propia y ofrecerlos para su actuación en el juicio.

De ese modo, cuando se habla del deber de descubrimiento de la Fiscalía, se incluye no solo el material probatorio sobre el cual reposa su acusación, sino también los elementos materiales y la evidencia favorable al imputado (a los cuales este no tiene acceso), pues el aparato estatal (Fiscalía) cuenta con mayores recursos humanos, económicos, técnicos, científicos y operativos de los disponibles para aquel; la defensa, en virtud del discover, examina, antes del juicio, los documentos y demás fuentes de prueba en posesión de la Fiscalía que pudieran favorecerle, para preparar su estrategia y teoría del caso.

Esta obligación de "descubrir pruebas" se impone también a la defensa, que debe poner a disposición de la Fiscalía los medios de prueba de cargo encontrados durante su propia investigación. Ninguna de las partes está autorizada a guardar secretos a la parte contendiente, a menos que lo respalde su derecho a no autoincriminarse.

también se reconozcan los de las partes-. Pero, naturalmente, las partes gozan de la plenitud de las garantías propias de un proceso que es de partes, pues estas deducen pretensiones, aunque no sean titulares del derecho de penar. El proceso adversarial es peligroso, pues una excesiva privatización conduce a la merma de la defensa o a que la misma solo pueda ser actuada por quienes tienen una posición económica determinada. El nuevo Código Procesal Penal peruano es un proceso que se hunde en el modelo acusatorio, sin rasgo alguno adversarial, aunque, naturalmente, reconozca el principio de oportunidad y los intereses de los perjudicados u ofendidos. No obstante, como conclusión, es imposible hoy definir los procesos con arreglo a categorías abstractas, pues todas tienen o soportan combinaciones, importaciones y medidas que son de los contrarios. Pero, insisto, lo esencial, es el carácter del delito y del proceso": "Estado de la reforma procesal en España". <http://www.lozavalos.com.pe/alertainformativa/index.php?mod=c ontenido\&com $=$ contenido\&id=2295>. [Consulta: 1 de setiembre del 2011.] 
Entendida entonces la figura del discover, su aplicación no tiene sentido en nuestro sistema. En el Perú, la única manera en que se pueden realizar actos de investigación es mediante la Fiscalía, que tiene la obligación de practicar tanto las diligencias sustentatorias de su acusación como las exculpatorias de responsabilidad del imputado. Por su parte, la defensa no puede practicar diligencias por cuenta propia, obviando la intervención de la Fiscalía: los testimonios, documentos y evidencias que pretenda introducir al juicio deben haber sido ofrecidos previamente a la Fiscalía - salvo el caso de la prueba nueva-, la que está en la obligación de examinarlas e incorporarlas en la carpeta fiscal a disposición de la defensa.

Por ello, en sistemas como el nuestro, el discover no tiene cabida. Aunque la Fiscalía solo ofrezca para su actuación en juicio medios de prueba de cargo, la defensa - accediendo a la carpeta fiscal- puede tomar conocimiento de todos los medios de prueba de descargo para aportar al juicio. Por su parte, la Fiscalía conoce que sólo lo obrante en la carpeta fiscal puede ser ofrecido para su actuación en el juicio por la defensa.

En consecuencia, en nuestro sistema, el que no exista obligación de "descubrimiento de pruebas" para las partes tampoco es una desventaja al momento de negociar.

Sí advertimos como desventaja - tanto para la defensa como para la Fiscalía - negociar con desconocimiento de la teoría del caso de la contraparte. El convenir sobre tal o cual hecho o prueba que no perjudica mi teoría del caso, puede resultar beneficiando a la teoría del caso de mi contraparte. Por eso, una vez más, señalamos que una convención probatoria es una decisión estratégica.

Esta desventaja puede ser superada si las partes al negociar una convención probatoria hacen conocer a su contraparte su teoría del caso; sin embargo, siempre será bueno preguntarse: ¿qué es lo más conveniente: mantener en reserva mi teoría del caso o arribar a una convención probatoria? La respuesta no es fácil, pero corresponderá a las partes efectuar su propia evaluación, según el caso concreto. 
c) El plazo establecido para la presentación de las convenciones es insuficiente.

Las convenciones probatorias deben ser propuestas al juez dentro de los diez días siguientes a la notificación de la acusación, plazo en el que es difícil que las partes arriben a un acuerdo, pues no está prevista la realización de una audiencia previa. Deben ser ellas quienes por propia iniciativa celebren reuniones privadas, lo que de por sí resulta difícil en la mayoría de los casos.

Creemos que el momento ideal para arribar a una convención probatoria es la audiencia preliminar, después de que ambas partes han ofrecido los medios de prueba que se actuarán en el juicio. En gran medida, como se ha anticipado, deben develar su teoría del caso para fundamentar la pertinencia de la prueba.

Corresponderá entonces solicitar la suspensión de la audiencia preliminar por breve término, para que las partes negocien sobre la posibilidad de arribar a convenciones probatorias.

Con ello se superaría lo limitado del plazo para su presentación y se facilitaría la negociación de las partes, quienes acudirán a la audiencia teniendo en cuenta la posibilidad de negociar con su contraparte respecto a hechos o medios de prueba, sin temor a que la solicitud sea desestimada por no haberse realizado en el plazo previsto por ley.

Corresponde, en consecuencia, realizar una modificación legislativa sobre la oportunidad de la postulación o presentación de las convenciones probatorias, otorgando a las partes la posibilidad de celebrarlas durante la audiencia preliminar.

Veamos un caso anecdótico. En el portal del Ministerio Público se informa de la celebración de una convención probatoria en una audiencia de prisión preventiva por delito de robo en grado de tentativa, en el distrito judicial de Ilo. ${ }^{34}$ Según la nota, después de que el fiscal sustentó su pedido y expuso los elementos de convicción con los que contaba, este, el imputado y su defensor llegaron a una convención probatoria dando por ciertos los hechos expuestos en el requerimiento de prisión preventiva. En virtud del

34 Ciudad ubicada al sur de Lima (a una distancia de 1,280 km), perteneciente al distrito judicial de Moquegua. 
acuerdo, el juez de investigación preparatoria declaró fundado el pedido y el imputado fue puesto en detención. ${ }^{35}$

En este caso, surge la inquietud respecto a qué es lo más conveniente o congruente con la celeridad procesal para el caso en particular. ¿Declarar fundada la convención probatoria y ordenar la prisión preventiva del imputado o, ante la aceptación de los hechos, propiciar una salida alternativa que ponga fin al conflicto y evitar un juicio oral? Probablemente, muchos de nosotros habríamos optado por lo segundo.

d) Obligación de presentar el acuerdo por escrito.

Según el artículo 350.2 del CPP04, las convenciones probatorias deben presentarse por escrito. Ello no privilegia los principios sobre los que se basa el sistema acusatorio; por el contrario, es un rezago de escrituralidad que debe ser superado.

Si las partes convienen en la convención probatoria, la exponen, sustentan y expresan su conformidad ante el juez, no debe ser necesaria presentarla por escrito, sobre todo cuando las propuestas de las partes, su contenido y las resoluciones que al respecto emita el juez constan en audio y video (o solo audio) y, por expresa disposición del CPP04, deben ser incorporados en el auto de enjuiciamiento (artículo 352.636).

En consecuencia, y en congruencia con el principio de oralidad, debe eliminarse el requisito de presentar el acuerdo por escrito.

\subsection{Causas culturales}

a) Se impone la cultura del litigio y la confrontación.

Debido a que las instituciones de justicia negociada han sido introducidas en la legislación peruana con el CPP04, la negociación no ha sido una práctica cotidiana en el quehacer de nuestros

35 Nota periodística del 26 de febrero del 2010. “Convención probatoria en audiencia de prisión preventiva". <http://www.mpfn.gob.pe/prensa-imprime. php?id=3131>. [Consulta: 10 de enero del 2011.]

36 "La resolución sobre las convenciones probatorias, conforme a lo dispuesto en el numeral 2) del artículo 350, no es recurrible. En el auto de enjuiciamiento se indicarán los hechos específicos que se dieren por acreditados o los medios de prueba necesarios para considerarlos probados". 
actores procesales: fiscales y abogados, formados y acostumbrados a la confrontación, a la primacía de la práctica del enfrentamiento.

Impera la cultura del litigio y no la del diálogo, y es eso lo que impide la aplicación de esta figura procesal. Los abogados, hasta hace algunos años, hemos sido preparados para pelear, para destruir al adversario y probablemente no entendamos la nueva lógica de la justicia penal - cuyo objeto es la solución de conflictos-, la fórmula ganar-ganar, en pos de la cual cada una de las partes debe ceder un interés en aras de obtener un beneficio. En un panorama como ese, el rol de los abogados no debe ser de confrontación, sino el de facilitadores del diálogo y la comunicación con la contraparte, con miras a hallar una verdadera solución al conflicto penal.

Tanto abogados como fiscales, que hemos ejercido el derecho dentro de la cultura del litigio y la confrontación, ahora debemos aprender las nuevas técnicas que exige el sistema acusatorio, lo cual implica reformular nuestros criterios y habilidades profesionales. Las nuevas generaciones de abogados y fiscales requieren una nueva capacitación y ser formados en la cultura del diálogo y la búsqueda de soluciones negociadas.

Abandonar las viejas prácticas significa olvidar lo aprendido y empezar de cero, con mentalidad abierta, que es como pedir volver a la escuela. Solo queda capacitarnos e interiorizar la cultura acusatoria recogida por el CPP04.

Otro aspecto que se debe tener en cuenta es la anacrónica y errada idea de muchos abogados, quienes si bien piensan en la justicia negociada como un mecanismo positivo para la economía procesal, no lo conciben así para su propia economía, pues calculan sus honorarios en proporción directa a la duración del proceso. No entienden aún que terminar un proceso penal en el menor tiempo posible, con una solución satisfactoria para ambas partes, implica éxito, y que el éxito - en esos términos- debe ser aún mejor recompensado. Una concepción de esta naturaleza comporta un cambio en la política de fijar honorarios, con la mira de lograr que el diálogo y la negociación para la solución del conflicto sea el principal objetivo. 
b) Las partes no conocen este instituto procesal penal.

Este desconocimiento guarda estrecha relación con la falta de desarrollo normativo de las convenciones probatorias, a diferencia de las demás instituciones de justicia negociada.

Si en una reunión con un gran número de abogados y fiscales propiciáramos una conversación sobre el principio de oportunidad o terminación anticipada, es seguro que cada uno de los asistentes nos expondría su experiencia de participación en la aplicación de esas figuras. Sin embargo, si el tema fuera la convención probatoria, la gran mayoría - sin temor a equivocarnos - no participaría, pues no solo no la han aplicado, sino que además la desconocen.

No obstante, ese desconocimiento puede superarse con la modificación normativa que proponemos en el acápite respectivo y con el desarrollo del tema en capacitación de abogados, fiscales y jueces, que, dicho sea de paso, no ha sido incorporado aún como un tópico que se debe tratar.

c) Las partes no comprenden su utilidad.

Si empezamos a negociar con el objetivo de evitar un juicio y ello no se logra, las partes pueden entender que no tiene objeto continuar negociando. ¿Deben olvidar el diálogo y volver a la confrontación?

La respuesta es no. Las convenciones probatorias, aún sin llegar a un acuerdo, son útiles, pues permiten que en el juicio oral el debate (sobre los hechos y los medios de prueba) entre las partes sea ordenado y se dé en el menor tiempo posible, con lo que se evita un juicio oral largo y tedioso.

Por eso, remarcamos, las convenciones probatorias sí son útiles en la medida en que aligeran el juicio oral, concentran el debate sólo en lo controvertido y evitan actuaciones de medios de prueba innecesarios.

d) Las partes creen que siempre una de ellas pierde.

Esta idea está directamente vinculada a la cultura de litigio y confrontación, instigadora de la actuación de abogados y fiscales, quienes, como se acotó, no comprenden que la negociación, si bien implica ceder algunos intereses, tiene como fórmula inspira- 
dora ganar-ganar, es decir, conceder en un punto pero ganar en otro.

Ambas partes deben ganar. La proporción mayor o menor en la que gane una respecto a la otra no es un problema o deficiencia de las convenciones probatorias, sino que se debe solo a la habilidad y destreza de abogados y fiscales.

e) Ausencia de labor pedagógica del juez para propiciar el acuerdo; no asume el rol de conductor activo en la audiencia.

Ante la deficiencia normativa y el desconocimiento de las partes sobre las convenciones probatorias, corresponde al juez de investigación preparatoria desarrollar una labor pedagógica durante la realización de la audiencia preliminar. Si advierte la posibilidad de arribar a convenciones probatorias respecto a hechos o medios de prueba, debe propiciar la negociación con miras a ello.

Esta labor pedagógica del juez, de ningún modo puede ser concebida como contraria a su deber de mantenerse imparcial; por el contrario, debe entenderse como el fiel cumplimiento de su función, pues como encargado de la etapa intermedia del proceso, debe preparar el debate para el juicio oral de la mejor manera. Esto implica procurar que las partes, respecto a los hechos y medios de prueba no controvertidos, puedan arribar a acuerdos en virtud de los cuales no sean objeto de debate.

Ello, sin embargo, debe limitarse a propiciar, mas no a suplir el acuerdo de las partes y determinar de oficio qué hechos serán sometidos a debate o qué único medio de prueba - dentro de otras que tienen la misma finalidad - será actuado en el juicio oral.

La simplificación del juicio oral, aspiración de las convenciones probatorias, debe producirse solo a instancia de parte, en virtud de un acuerdo. Una cosa es que el juez propicie la negociación y el acuerdo, y otra completamente distinta es suplir a las partes. Su labor pedagógica estará cumplida cuando advierta la posibilidad de negociar y se lo haga saber a las partes, a quienes corresponde decidir si simplifican o no el juicio oral.

El juez debe ser flexible, permitiendo la postulación de convenciones probatorias durante la realización de la audiencia preliminar, es decir, aun después del plazo establecido por el CPP04 
(inciso 2 del artículo 350) para su presentación, que, referimos, es uno de los inconvenientes para la práctica de dichas convenciones.

\section{Conclusiones}

Revisadas las principales razones de la baja aplicación de las convenciones probatorias en el Perú, a más de cinco años de vigencia del CPP04, puede sostenerse que la principal acción que se debe ejecutar para incrementar su aplicación es promover el conocimiento de esta figura procesal penal entre los actores procesales. En esa labor, los jueces cumplen una función primordial, pues, conduciendo a diario audiencias, al advertir la posibilidad de arribar a convenciones probatorias son testigos de su falta de aplicación debido a que las partes no las conocen, bien porque las consideran innecesarias, bien porque continúan sumidas en la cultura del litigio y la confrontación. En situaciones así, los jueces deben conducir o invitar a las partes a conversar sobre la aplicación de estas convenciones, sin que se deje de lado la capacitación de los actores procesales respecto a estas y en técnicas de negociación.

1. La legislación peruana es la única legislación de las analizadas que permite a las partes arribar a estipulaciones o convenciones probatorias respecto a medios de prueba.

2. La forma de presentar las convenciones probatorias legisladas por el CPP04 no se encuentra en concordancia con el principio de oralidad, pues se exige que se presenten por escrito.

3. Las convenciones probatorias son las instituciones de justicia penal negociada menos aplicadas en el Perú, debido a que, a diferencia de las otras, no evitan el juicio oral, no obstante simplificarlo, ordenarlo y dinamizarlo. Estas bondades aún no son entendidas por las partes.

4. Los principales inconvenientes para la aplicación de las convenciones probatorias en el Perú obedecen a criterios de orden normativo y cultural, que pueden ser superados con la labor pedagógica del juez y la capacitación de los actores procesales. 


\section{Bibliografía}

AA.VV. (2005). El proceso penal acusatorio colombiano: nuevo manejo de la prueba. Tomo I. Primera reimpresión. Bogotá: Ediciones Jurídicas Andrés Morales.

Consejo Superior de la Judicatura (2005). “El rol de jueces y magistrados en el sistema penal acusatorio colombiano". Bogotá. <http://www. pfyaj.com/checchi/biblioteca/MANUAL_DEL_JUEZ.pdf >. [Consulta: 12 de enero del 2010]

Mixán Mass, Florencio (1992). Teoría de la prueba. Lima: BLG.

Quisbert, Ermo (s/f). "Circunstancias del delito". <http://enj.org/portal/ biblioteca/penal/teoria_delito/07.pdf $>$. [Consulta: 15 de febrero del 2011.]

RAE (Real Academia Española) (2001). Diccionario de la lengua española. 22. ${ }^{\text {a }}$ edición.

Rodríguez Baca, Nicolás (1997). La justicia penal negociada. Experiencias de derecho comparado. Salamanca: Universidad de Salamanca. <http:// books.google.com.pe/books?id=odn6Qmf4IMQC\&pg=PA29\&lpg $=$ PA29\&dq=plea + bargaining \&source $=$ bl\&ots $=$ ELzDZrr-Pw\&sig $=$ mSDw5tM5OmD5adURg_7ni9NcAYU\&hl=es\&ei=0-Z3TYn0KIT7 lwe4wbSQDg\&sa $=X \&$ oi $=$ book_result\&ct=result\&resnum $=8 \&$ ved $=0$ CGEQ6AEwBw\# $\mathrm{v}=$ onepage $\& \mathrm{q}=$ plea $\% 20$ bargaining $\& \mathrm{f}=$ false $>$. [Consulta: 3 de febrero del 2011.]

San Martín Castro, César (2003). Derecho procesal penal. Tomos I y II. 2. ${ }^{a}$ edición. Lima: Grijley.

Silva Corredor, Arévalo (2005). "Las estipulaciones probatorias", en El proceso penal acusatorio colombiano. Tomo I. Bogotá: Ediciones Jurídicas Andrés Morales. 